\title{
Transportation policy and the effects on modal choice in the EU
}

Citation for published version (APA):

Ribbink, D., van Riel, A. C. R., \& Semeijn, J. (2004). Transportation policy and the effects on modal choice in the EU. METEOR, Maastricht University School of Business and Economics. METEOR Research Memorandum No. 010 https://doi.org/10.26481/umamet.2004010

Document status and date:

Published: 01/01/2004

DOI:

10.26481/umamet.2004010

Document Version:

Publisher's PDF, also known as Version of record

\section{Please check the document version of this publication:}

- A submitted manuscript is the version of the article upon submission and before peer-review. There can be important differences between the submitted version and the official published version of record.

People interested in the research are advised to contact the author for the final version of the publication, or visit the DOI to the publisher's website.

- The final author version and the galley proof are versions of the publication after peer review.

- The final published version features the final layout of the paper including the volume, issue and page numbers.

Link to publication

\footnotetext{
General rights Owners
rights.

- You may freely distribute the URL identifying the publication in the public portal. please follow below link for the End User Agreement:

www.umlib.nl/taverne-license

Take down policy

If you believe that this document breaches copyright please contact us at:

repository@maastrichtuniversity.nl

providing details and we will investigate your claim.
}

Copyright and moral rights for the publications made accessible in the public portal are retained by the authors and/or other copyright owners and it is a condition of accessing publications that users recognise and abide by the legal requirements associated with these

- Users may download and print one copy of any publication from the public portal for the purpose of private study or research.

- You may not further distribute the material or use it for any profit-making activity or commercial gain

If the publication is distributed under the terms of Article $25 \mathrm{fa}$ of the Dutch Copyright Act, indicated by the "Taverne" license above, 


\title{
DINA RIBBINK ${ }^{1}$
}

\author{
ALLARD C. R. VAN RIEL ${ }^{2}$ \\ JANJAAP SEMEIJN ${ }^{3}$
}

Transportation Policy and the Effects

on Modal Choice in the EU

\begin{abstract}
This study addresses the question of how trans-national regulations could stimulate environmentally friendly transportation. Effects of capacity limitations, costs and transit time requirements on the attractiveness of different containerized transportation modes are modeled for a representative freight corridor in the European Union. Multiple legislative scenarios are developed for 2010, taking into account various characteristics of road, rail and inland waterway transportation, including costs to society and environmental costs. Analysis of the scenarios reveals that under the current legislation environmentally friendly transportation modes are already very attractive, but lack sufficient capacity to deal with demand. Further legislative interventions, such as increased taxation, would only lead to increased transportation costs, and render containerized transportation less effective and more costly to society. For a more favorable modal split, it appears that important investments are to be made in dedicated cargo rail and inland waterways.
\end{abstract}

\section{Introduction}

Over the past decades, transportation has increased dramatically in the

\footnotetext{
${ }^{1}$ Junior Lecturer in the Department of Marketing, Faculty of Economics and Business Administration, Maastricht University. P.O. Box 616, 6200 MD Maastricht, the Netherlands.

${ }^{2}$ Assistant Profesor in the Department of Marketing, Faculty of Economics and Business Administration, Maastricht University. P.O. Box 616, 6200 MD Maastricht, the Netherlands.

${ }^{3}$ Professor in the Department of Management Sciences, Faculty of Economics and Business Administration, Open University Netherlands. P.O. Box 2960, 6401 DL Heerlen, the Netherlands.
} 
European Union (EU) (CEC 2002). Growth rates vary significantly between prevailing transportation modes. Road usage increased exponentially, while the use of inland waterways and rail decreased (CEC 2001a). The European Commission (EC), the legislative body in the EU, is concerned that the trend, visualized in Table 1, will continue in the absence of timely intervention (CEC 1999).

\section{Please Insert Table 1 about here.}

Increased yearly tonnages and the steadily increasing share of road transportation - from about 50 percent in 1970 to 75 percent in 1999 - have led to severe and chronic congestion (CEC 2002). Average traffic speed has decreased by 10 percent over the last 10 years in major OECD cities (OECD 1995). Six percent of fuel is consumed in traffic jams and delays (CEC 2001a), reflecting an economic loss of two percent of GDP (CEC 2001c).

The EC currently intervenes in the organization of European transportation by imposing fuel taxes, and designing environmental guidelines and regulations. Some national governments have imposed additional ecological taxes ${ }^{\mathrm{i}}$. The EC proposes to further alleviate the problems by means of new and stricter common transport policies, which, in essence, pass on to carriers and shippers the true costs to society and the environment (CEC 2001a).

The potential effectiveness of additional EC measures is subject to controversy. While ecologists demand better protection of the environment and insist that the carriers should pay for the pollution and the damage caused, carriers argue that further interventions will lead to increased costs and job losses. European citizens have a mixed view on the subject. Strict regulation is generally favored, to reduce dangerous emission levels (Stanners et al. 1995). However, the public is unwilling to pay the corresponding costs. 
A major aim of the present study is to develop a better understanding of the potential effects of centralized policy decisions on the transportation market, and the conditions under which such decisions could be effective. The results could support EU transportation policy makers in determining new intervention measures.

The study is guided by the following research questions:

- Research Question 1: How would passing on of all environmental and social costs affect the attractiveness of various transport modes in $2010 ?$

- Research Question 2: How will capacity limitations and speed requirements affect the attractiveness of various transport modes in 2010 ?

\section{Approach}

In a literature review, factors influencing modal choice decisions are identified for containerized cargo. A model is developed, based on a study by Van Ierland et al. (2000). The effects of various policies are examined by comparing the relative attractiveness of road, regular cargo rail, dedicated cargo rail, and inland waterway in a heavily used freight corridor using different scenarios. Finally, limitations of the study as well as opportunities for further research are identified.

\section{Factors Affecting the Attractiveness of Transportation Modes}

Modal choice is generally driven by a company's desire to remain competitive by serving their customers both effectively and efficiently. Three factors determine the attractiveness of containerized transportation offers to a large extent: costs, time in transit, and reliability of transit time (Cullinane et al. 2000; McGinnis et al. 1981). Several studies indicate that the reliability of promises regarding transit time is more important than the duration of the transit itself (Murphy et al. 1997; Premeaux 2002;

Semeijn et al. 1995). Typically, transportation studies compare selection criteria 
within one specific mode. In spite of its strategic importance, modal choice is rarely investigated. For this study, it is assumed that the principal modal choice criteria are similar to carrier selection criteria, i.e. decision-makers attempt to minimize costs while maximizing speed and reliability.

\section{Costs}

Transportation costs are mainly determined by fuel prices, efficiency of the transportation mode and taxes. An important recent change in the attitude of European policy makers is the idea that transportation costs should reflect the true costs to environment and society. Based on this idea, a policy framework is developed, to be implemented by 2005 (CEC 2001b). ${ }^{\text {ii }}$ Environmental impacts of transportation not only include the consumption of energy, but also the emissions of carbon monoxide $(\mathrm{CO})$, carbon dioxide $\left(\mathrm{CO}_{2}\right)$, sulfur dioxide $\left(\mathrm{SO}_{2}\right)$, nitrogen oxides $\left(\mathrm{NO}_{\mathrm{x}}\right)$ and hydrocarbons; $\mathrm{SO}_{2}$ and $\mathrm{NO}_{\mathrm{x}}$ are two known causes of acid rain. Nitrogen oxides indirectly contribute to the greenhouse effect and directly to smog (Stanners et al. 1995). The environment is substantially burdened by the side effects of transportation, but the effects tend to vary per transportation mode. Compared to transportation via rail and inland waterways, road transportation produces about four times the nitrogen oxides, sulfur and carbon dioxide emissions per ton-km (Van Ierland et al. 2000).

Transportation's costs to society include noise and light pollution, as well as accidents. Up to 30 percent of the population of the EU is exposed to noise levels above $65 \mathrm{~dB}$ (A) due to road traffic (OECD 1994), while 5-15 percent of the population is suffering from serious noise-induced sleep disturbances (CEC 2001c). Furthermore, traffic accidents are the principal cause of accidental death in the EU. In the year 2000 more than 40,000 people were killed and over 1.2 million injured (CEC 
2002). The associated loss of productivity accounts for further economic losses. In 1995, costs of road accidents have been estimated to amount to 406 billion Euros per year (Beuthe et al. 2002). Again, large differences exist between different transportation modes: The number of casualties in rail transportation and inland waterway shipping is negligible compared to road transportation (CEC 2002). ${ }^{\mathrm{iii}}$

\section{Speed and Reliability}

Speed and reliability are determined by the characteristics of each mode, and capacity limitations of the existing infrastructure.

Since the deregulation of the EU motor carrier industry in 1993, the establishment of Pan-European Corridors (PAN) has been encouraged by the EC (Lewis et al. 2001/2002). Increased liberalization has led to a more efficient transport system by, for instance, allowing cabotage. However, deregulation has not led to a measurable reduction in transportation rates in Europe (Gentry et al. 1995), as was the case in the USA and Canada (Bardi et al. 1989). Operating expenses have been steadily increasing due to high fuel prices and road charges, more than offsetting any rate cuts. Severe and chronic congestion currently affect average speed and reliability of the road transportation network. Passages across mountains and waterways are also problematic. Austria and Switzerland have imposed restrictions on motor carrier movements in their countries. Germany and France - among other EU countries restrict weekend traffic of trucks (Lewis et al. 2001/2002), further decreasing the attractiveness of road haulage.

The operational part of the European railway network has decreased in length by about 10 percent over the past three decades (CEC 2002). Certain track extensions have been eliminated, while key connections share the infrastructure with passenger 
transportation, and consequently have to deal with very tight schedules. Bottlenecks are also formed by bridges, passes across mountains and tunnels (CEC 2001a). Varying levels of railway privatization across EU countries reflect another weakness; publicly owned systems are generally less efficient (Gentry et al. 1995). A focus on national priorities often impedes cross border traffic. Unlike information systems for passenger rolling stock, the systems for freight transportation are not integrated and standardized across the EU. This lack of integration and standardization creates many difficulties including long border delays. The opening of all markets by EU legislation, in force since March 15, 2003, is expected to bring about some changes. In countries such as Germany and the Netherlands, poor rail cargo performance can be attributed to the prioritization of passenger transportation (Lewis et al. 2001/2002). Still, the EC has recognized the potential of rail as an economically viable, environmentally friendly mode of transportation. The 'Essen list', containing transportation infrastructure projects subsidized by the EU, is an attempt to enforce more environmentally friendly transportation in Europe (CEC 2001a).

A comprehensive network of inland waterways exists throughout Europe, but it is in need of extension and modernization. Plans have been developed for hundreds of years (Sidaway et al. 1995), but only few projects have been realized ${ }^{\text {iv }}$. Public opposition, financial constraints and bureaucracy have hindered the construction of new shipping channels or the modernization of existing waterways, affecting the competitiveness of waterway transportation in terms of speed, capacity and reliability. Even though the Gothenburg European Council specifically asked for a balanced development of the infrastructure (CEC 2001b), only one out of seventeen projects subsidized by the EU was related to waterways. In some areas, e.g. in the Rhine Basin, the available network of inland waterways is already well exploited. 
Elsewhere, transportation on water has only recently started to gain some momentum (Campisi et al. 1996). A strong emphasis on transit time reduction reduces the attractiveness of inland waterway shipping.

\section{Propositions}

Based on the foregoing, four propositions were developed, two for each research question. Propositions one and two address the passing on of environmental and social costs to carriers. The third proposition examines the effects of infrastructural capacity limitations, while the fourth proposition examines the effects of differences in transit time requirements.

P1: Legislative actions such as imposing taxes on emissions increase the attractiveness of environmentally friendly modes of transportation, which leads to an increase of their relative share.

P2: Imposing additional taxation on transportation, to reflect social and environmental costs, would change the relative attractiveness of different modes.

P3: Infrastructural capacity limitations will neutralize or counteract the legislative actions.

P4: Modal choice is dependent on transit time requirements.

\section{Research Design and Methodology}

The relative attractiveness of various modes of containerized transportation is investigated in the freight corridor between the Ruhr Basin (Germany) and the Port of Rotterdam (the Netherlands), which serves as an exemplary setting for EC transportation policy decisions. ${ }^{\mathrm{v}}$ This corridor has been the subject of previous academic and governmental policy studies (e.g. Betuweroute 2004; Van Ierland et al. 
2000), because of its unique role within European transport, and the public availability of detailed information, allowing an academic examination of potential effects of various policy decisions. The Ruhr Basin is the largest modern industrial area in Europe and Rotterdam is Europe's largest port. Interestingly, a new electrified rail link will be established in this area by 2006: the Betuwe-line, with a length of 160 $\mathrm{km}$, will be a dedicated cargo rail connection between the port of Rotterdam and the Dutch-German border. All data pertaining to this route are estimated on the basis of forecasts by the Dutch government (Betuweroute 2004). To connect the Ruhr Basin, Dutch and German railway companies have agreed upon the further construction of exclusive cargo tracks.

\section{The Model}

In a cost minimization model, the relative attractiveness of three transportation modes and the resulting modal split are explored for containerized goods for the year 2010. The sum of products of 1) the number of vehicles used $(\mathrm{N}), 2)$ the distance traveled by the vehicles using a specific transportation mode ( $\mathrm{D}$ in $\mathrm{km}), 3)$ the respective weight carried per vehicle (W in tons), and 4) the respective costs per ton$\mathrm{km}(\mathrm{C}$ in $€ /$ ton-km) for all five available transportation modes $(\mathrm{T})$ is minimized. Formally, the model can be represented by:

$$
M I N \quad X=\sum_{T=1}^{T=5} N_{T} D_{T} W_{T} C_{T}
$$

In the model, the total sum of costs is minimized. The number of vehicles per transportation mode $(\mathrm{N})$ is calculated, while the values provided in Table 2 are used in the other variables. This model is applied to a range of scenarios to examine the effects of changes in transport regulations and taxation for three transit time requirement distributions for three transportation modes, resulting in a three by three 
scenario-matrix. In all scenarios, it is assumed that 60.424 billion ton-km must be transported from the Ruhr Basin to Rotterdam in the year 2010. ${ }^{\mathrm{vi}}$ The study follows Van Ierland et al. (2000), who modeled the attractiveness of various modes using five different scenarios for 1995-2020. They forecasted a modal split using three different kinds of trucks, regular rail, dedicated cargo rail and inland waterway shipping. In this study, the same modes are used, but modal split is calculated for three different levels of taxation, using three levels of transit time urgency.

\section{Levels of Regulations and Taxation}

The first step in generating the scenarios consists of the development of three fiscal regimes. These regimes represent likely future combinations of transportation regulations and taxation policies in force in 2010.

1) The current fiscal situation in Germany is applied, indexed for $2010^{\mathrm{vii}}$. This regime was chosen to reflect no further government intervention.

2) The current annual German national ecological taxation increase will continue and be generally applied through 2010. With regard to road haulage this consists of a supplementary tax, annually increasing by 3.07 Euro-Cents per liter diesel fuel. Regarding rail transportation, an ecological tax on electricity has been imposed in 1999, of 2 percent per $\mathrm{kW} / \mathrm{h}$, subsequently indexed annually at 0.26 Euro-Cents per $\mathrm{kW} / \mathrm{h}$ (SPD 2000). Fossil fuel used by inland waterway transportation is currently not taxed. For this regime, we assume a level of taxation similar to rail. ${ }^{\text {vii }}$

3) All costs to society and the environment are passed on to carriers. Social costs for road transportation are included as a fixed proportional amount of $0.01 € /$ ton-km. The costs of $\mathrm{CO}_{2}$ emissions to society are estimated at $0.05 € / \mathrm{kg}$, those of $\mathrm{NO}_{\mathrm{x}}$ at $15.11 € / \mathrm{kg}$ and $\mathrm{SO}_{2}$ at $3.49 € / \mathrm{kg}$ (adapted from Koomey et al. 1997). 


\section{Transit Time Requirements}

The second step in generating the scenarios consists of establishing different levels of transit time urgency. Transit time, the time needed to move the container from place of departure to place of arrival, plus the loading times at the places of departure and arrival, is an important modal choice criterion. Therefore, each regime is investigated for three different transit time requirements, reflecting the distribution of levels of urgency. Setting A is closest to the actual state of affairs.
A. 80 percent of shippers require a maximum transit time of five hours.
B. 60 percent of shippers require a maximum transit time of five hours.
C. 40 percent of shippers require a maximum transit time of five hours.

Table 2 provides further details about the various assumptions.

\section{Please Insert Table 2 Here}

For 2010, a capacity limitation to the road infrastructure in the Ruhr Basin Rotterdam corridor of 35 billion ton- $\mathrm{km}^{\mathrm{ix}}$ was used. Similar to the study by Van Ierland et al. (2000), three categories of trucks are used, representing different levels of efficiency and $\mathrm{CO}_{2}, \mathrm{NO}_{\mathrm{x}}$, and $\mathrm{SO}_{2}$ emissions (see Table A-1): Truck 3 is the most efficient and has the lowest emission levels; Truck 1 is the least efficient and pollutes most. Even though it is desirable to have only the most modern and therefore most efficient trucks running, newer models are expected to only gradually replace the older trucks (see Table 2).

\section{Dedicated Rail versus Regular Rail}

It was decided to run the simulation in all scenarios for both regular (old) rail and dedicated (new) rail. These rail options are considered mutually exclusive: Until the completion of the Betuwe-line on the Ruhr - Rotterdam corridor, regular rail is the only available rail link. As soon as the Betuwe-line is operational, regular rail is 
rendered obsolete as a result of the significant improvements in speed and service offered. Cost figures from analyses of old and new rail can be found in Tables A-2 and A-3 in the Appendix; a comparison of costs per ton-km reveals that those scenarios including the Betuwe-line outperform regular rail.

\section{Results}

Results of the analyses are displayed in Tables 3 and 4.

\section{Please Insert Tables 3 and 4 Here}

A comparison of Tables 3 and 4 (all scenarios including regular rail versus all scenarios including dedicated rail) demonstrates that continued use of regular rail on the Ruhr - Rotterdam corridor is not realistic from a volume of traffic perspective, for any of the scenarios, except in the lowest urgency (40 percent) settings. Based on the volume predictions (60.424 billion ton-km), dedicated rail (Betuwe-line) appears to be a necessity. Further discussion of the results for the different scenarios will therefore focus on the dedicated rail case (Table 4).

Social cost and pollution figures are most favorable under the slow time settings due to the extensive use of both river barges and rail, and reliance on type 2 and 3 trucks only. As the urgency of shipments increase, fewer barges and more type 2 trucks are employed, elevating the social costs and pollution figures. Closer examination of the increasing tax levels reveals that increased taxation has little effect on the proportion of each mode used, i.e., increased taxation levels lead to increased costs, while not effecting modal usage. Therefore, no basis was found to support propositions 1 and 2, concerning the effects of regulations on the relative attractiveness of the various modes. Regarding proposition 3, concerning the effect of capacity limitations on the usage of different modes, the following applies: Truck 1 is 
always used to its minimum usage requirement. Truck 3 is almost always used to capacity. When more road capacity is needed, the share of Truck 2 will therefore increase above its minimum, whereas the urgency requirements prevent inland waterway shipping from being utilized to its maximum capacity. The most attractive mode, dedicated rail also cannot fulfill demand, due to capacity limitations. These findings render proposition 3 plausible. Results also support proposition 4, relating the effect of transit time requirements to modal choice. The introduction of different transit time requirements in the simulation led to considerable shifts in modal usage.

\section{Discussion and Conclusion}

How would passing on of true environmental and social costs affect the attractiveness of various transport modes in the next decade? The simulation shows that additional EU legislative measures would not result in a more environmentally friendly modal split. Current energy costs apparently reflect environmental costs sufficiently, leading to increased attractiveness of energy efficient modes such as waterways and rail. Additional measures simply lead to increased transportation costs.

Due to existing taxes and the relatively low exploitation costs of the Betuweline, the first regime already stimulates an environmentally friendly modal split. The effect of introducing dedicated rail could be observed by the comparison with regular

rail. Results indicate that transporting containerized goods by dedicated cargo rail will remain cheaper and environmentally friendlier than either road or inland waterway shipping, while approximating the speed and reliability of road transportation.

Do capacity limitations have an effect on modal choice? Yes, infrastructural capacity limitations cause a shift towards road transportation. Since dedicated cargo rail is competitive in terms of costs and time, it will be utilized to full capacity. If only 
40 percent of shippers would require a short transit time, inland waterway transportation would also reach full capacity. Road haulage is found to carry all surplus traffic. The Betuwe-line could achieve similar transit times as road haulage, but at lower costs, whereas inland waterway shipping is slower, but very competitive in terms of costs. The inclusion of transit time substantially influences the relative attractiveness of the various modes.

\section{Recommendations}

Findings suggest that to achieve a more balanced distribution across the different modes, policy makers within the EU need not impose further taxes on road transportation, provided that there is sufficient capacity available in other modes. Current fuel taxes sufficiently influence transportation costs and therefore modal choice. With fewer trucks on the road the toll of road accidents will likely decrease. An increase in the utilization of freight trains and inland waterway shipping will lead to lower emissions of carbon dioxide, nitrogen oxides and sulfur dioxide. Although barges are more environmentally friendly than trucks, the EU may actually decide to tax them. To a certain extent this would be possible without affecting the relative attractiveness of this mode. Such a decision could help pay for the extension of the existing waterway network and compensate for environmental damage.

The lack of timely and fast alternatives appears to be the principal reason for the use of road transportation. The introduction of dedicated cargo rail links such as the Betuwe-line could change this situation. To further persuade the transportation market towards a more environmentally friendly modal split, the EC should therefore support dedicated cargo rail projects. Additional taxation of the Betuwe-line also appears feasible, without affecting the attractiveness of this mode. These taxes could be used to pay back the investments. 


\section{Limitations}

The simulation focused on one specific route: Ruhr Basin - Rotterdam, downstream. The distance involved is relatively short and there is little difference between different modes in this respect. For other freight corridors the gaps between different modes could be larger. Therefore, the generalizability of the results needs further investigation.

Negative effects on the environment and costs of transportation to society are difficult to quantify. In the model, only emissions of carbon dioxide, nitrogen oxides and sulfur dioxide are used. Light and noise pollution, opportunity cost of land use and other emission factors are side effects of transportation and their quantification and inclusion in the model could increase the validity of this study, while adding to the cost disadvantage of road transportation.

\section{Further Research}

The enlargement of the EU creates opportunities, since the new member states have different infrastructures in place. Road systems are often of lower quality and heavily congested, which results in longer transit times for trucks (Lewis et al. 2001/2002). However, compared to the road network, railway systems are in reasonable shape (Blaha et al. 1990/1991). To stimulate economic growth, the EC could impose regulations preventing the demise of established rail systems. More importantly, after having joined the EU, the Eastern European countries will now have to comply with EU laws concerning emission factors. The consequences for business and society remain to be investigated. Research is needed to help the new EU members to avoid making the same mistakes as Western Europe, i.e. developing road transportation at the expense and neglect of reliable alternative transport modes. 
References

Bardi, Edward J., Prabir K. Bagchi, and T.S. Raghunathan (1989), "Motor Carrier Selection in a Deregulated Environment," Transportation Journal, 29(1), pp. 4-11.

Betuweroute (2004) "Betuweroute Information Website," www.betuweroute.nl. Beuthe, Michel, Fabrice Degrandsart, Jean-François Geerts, and Bart Jourquin (2002), "External Costs of the Belgian Interurban Freight Traffic: A Network Analysis of Their Internalisation," Transportation Research: Part D, 7(4), pp. 285-301.

Blaha, Jaroslav and Michèle Kahn (1990/1991), "Transportation in the East: The Key to Trade between the Two Europes," Eastern European Economics, 29(2), pp. 29-63.

Campisi, Domenico and Massimo Gastaldi (1996), "Environmental Protection, Economic Efficiency and Intermodal Competition in Freight Transport," Transportation Research: Part C, 4(6), pp. 391-406.

CEC (1999). Communication to the European Parliament, the Council, the Social and Economic Committee and the Committee of the Regions - the Development of Short Sea Shipping in Europe. Brussels: Commission of the European Communities.

CEC (2001a). European Transport Policy for 2010: Time to Decide. Luxembourg: Commission of the European Communities.

CEC (2001b). A Sustainable Europe for a Better World: A European Strategy for Sustainable Development. Brussels: Commission of the European Communities.

CEC (2001c) "Utopia - Final Report for Publication," http://europa.eu.int/comm/transport/extra/final_reports/urban/utopia.pdf.

CEC. (2002), EU Energy and Transport in Figures - Statistical Pocketbook 2002. Luxembourg: European Commission.

Cullinane, Kevin and Neal Toy (2000), "Identifying Influential Attributes in Freight Route/Mode Choice Decisions: A Content Analysis," Transportation Research: Part E, 46(1), pp. 41-53. 
Gentry, Julie J., Janjaap Semeijn, and David B. Vellenga (1995), "The Future of Road Haulage in the New European Union - 1995 and Beyond," Logistics and Transportation Review, 31(2), pp. 145-159.

Koomey, Jonathan and Florentin Krause. 1997. Introduction to Social Externality Costs. In F. Kreith \& R. E. West (Eds.), Handbook on Energy Efficiency: 153164. Boca Raton, Fl.: CRR Press.

Lewis, Ira A., Janjaap Semeijn, and David B. Vellenga (2001/2002), "Issues and Initiatives Surrounding Rail Freight Transportation in Europe," Transportation Journal, 41(2/3), pp. 23-31.

McGinnis, Michael A., Thomas M. Corsi, and Merrill J. Roberts (1981), "A Multiple Criteria Analysis of Modal Choice," Journal of Business Logistics, 2(2), pp. 48-68.

Murphy, Paul R., James M. Daley, and Patricia K. Hall (1997), "Carrier Selection: Do Shippers and Carriers Agree, or Not?," Transportation Research Part E, 33(1), pp. 67-72.

OECD (1994). Ministerial Session on Transport and the Environment: Backgroup Reports. Paris: OECD and ECMT.

OECD (1995). Urban Travel and Sustainable Development. Paris: OECD and ECMT.

Premeaux, Shane R. (2002), "Motor Carrier Selection Criteria: Perceptual Differences between Shippers and Motor Carriers," Transportation Journal, 42(2), pp. 2838.

Semeijn, Janjaap and David B. Vellenga (1995), "International Logistics and OneStop Shopping," International Journal of Physical Distribution and Logistics Management, 25(10), pp. 26-44.

Sidaway, C., T.J. Price, and S.D. Probert (1995), "Transportation Via Canals: Past, Present and Future," Applied Energy, 51(1), pp. 1-17.

SPD (2000) "Die Öko-Steuer," http://www.spdfraction.de/archiev/oekosteuer3/neuregelungen.html.

Stanners, D. and P. Bourdeau. (1995), Europe's Environment: The Dobris Assessment. Copenhagen: European Environment Agency.

Van Ierland, Ekko C., Cor Graveland, and Robert G.J. Huiberts (2000), "An Environmental Economic Analysis of the New Rail Link to European Main Port Rotterdam," Transportation Research: Part D, 5, pp. 197-209. 
Table 1: Evolution of modal split in the $\mathrm{EU}^{4}$

\begin{tabular}{lllc}
\hline & Road & Rail & Inland Waterways \\
\hline $\mathbf{1 9 7 0}$ & $52.0 \%$ & $30.2 \%$ & $10.9 \%$ \\
$\mathbf{1 9 8 0}$ & $59.9 \%$ & $24.2 \%$ & $8.9 \%$ \\
$\mathbf{1 9 9 0}$ & $69.2 \%$ & $18.2 \%$ & $7.6 \%$ \\
\hline $\mathbf{2 0 0 0}$ & $74.6 \%$ & $13.8 \%$ & $6.9 \%$ \\
\hline
\end{tabular}

Adapted from: (CEC 2002)

${ }^{4}$ This table does not include the modal share of pipelines; therefore the percentages do not add up to $100 \%$. 
Table 2: Assumptions Relating to the Transportation on the Ruhr Basin-Rotterdam Corridor ${ }^{1}$

\begin{tabular}{|c|c|c|c|c|c|c|c|}
\hline Mode: & \multicolumn{4}{|c|}{ Road } & \multirow{2}{*}{ Betuwe-line } & \multirow{2}{*}{ General Rail Cargo } & \multirow{2}{*}{ Inl. Waterways } \\
\hline & & Truck 1 & Truck 2 & Truck 3 & & & \\
\hline TEU (tonnage) & & $1(25 t)$ & $1(25 t)$ & $1(25 t)$ & $35(875 t)$ & $35(875 t)$ & $268(6700 t)$ \\
\hline Distance in km (miles) & \multicolumn{3}{|c|}{$230(143)$} & & $240(149)$ & $240(149)$ & $234(145)$ \\
\hline Av. speed in $\mathrm{km} / \mathrm{h}(\mathrm{mph})$ & & $65(40)$ & $65(40)$ & $65(40)$ & $90(56)$ & $18(11)$ & $15.6(9.7)$ \\
\hline Transit time (hours) & \multicolumn{4}{|c|}{3.54} & 2.66 & 13.33 & 15.00 \\
\hline Loading times (hours) & \multicolumn{4}{|c|}{.17} & .75 & .75 & 1.91 \\
\hline Un-loading times (hours) & \multicolumn{4}{|c|}{.17} & .50 & .50 & 1.91 \\
\hline Total transit time (hours) & \multicolumn{4}{|c|}{3.88} & 3.92 & 14.58 & 18.83 \\
\hline Fuel cost (euro) & \multicolumn{4}{|c|}{1.00 per liter } & .11 per $\mathrm{kWh}$ & .11 per $\mathrm{kWh}$ & .50 per liter \\
\hline Capacity (billion ton-km) & 35 & $5<X<20$ & $2.5<\mathrm{X}$ & $X<10$ & 10.6 & $3.53^{\#}$ & 35 \\
\hline \multicolumn{8}{|l|}{ Emission levels } \\
\hline $\mathrm{CO}_{2}(\mathrm{~g} /$ ton-km$)$ & & 155.00 & 150.00 & 145.00 & 39.00 & 39 & 32.00 \\
\hline $\mathrm{NO}_{\mathrm{x}}(\mathrm{g} /$ ton-km) & & 2.80 & 2.10 & 1.40 & .62 & .62 & .06 \\
\hline $\mathrm{SO}_{2}(\mathrm{~g} / \mathrm{ton}-\mathrm{km})$ & & .17 & .14 & .11 & .04 & .04 & .06 \\
\hline Energy factor (MJ/ton-km) & & 1.82 & 1.61 & 1.40 & .45 & .45 & .72 \\
\hline
\end{tabular}


Table 3: Modal Split and Emissions in Year 2010 for three Transit Time Sensitivities Including Regular Cargo Rail

\begin{tabular}{|c|c|c|c|c|c|c|}
\hline \multirow{2}{*}{ Time Sensitivity: } & \multicolumn{2}{|c|}{$(80 \%)$} & \multicolumn{2}{|c|}{$(60 \%)$} & \multicolumn{2}{|c|}{$(40 \%)$} \\
\hline & Vehicles Used & Modal Split (\%) & Vehicles Used & Modal Split (\%) & Vehicles Used & Modal Split (\%) \\
\hline Trucks (1) & 869,565 & 8.3 & 869,565 & 8.3 & 869,565 & 8.3 \\
\hline Trucks (2) & $3,478,261$ & 33.1 & $3,478,261$ & 33.1 & $1,594,713$ & 15.2 \\
\hline Trucks (3) & $1,739,130$ & 16.5 & $1,739,130$ & 16.5 & $1,739,130$ & 16.5 \\
\hline Regular Cargo Trains & 16,825 & 5.8 & 16,825 & 5.8 & 16,825 & 5.8 \\
\hline Barges & 5,454 & 14.2 & 15,416 & 34.2 & 20,871 & 54.2 \\
\hline Total & & 77.9 & & 97.9 & & 100.0 \\
\hline \multicolumn{7}{|l|}{ Emissions } \\
\hline $\mathrm{CO}_{2}(\mathrm{~kg})$ & $5,671,573,867$ & & $6,142,881,067$ & & $4,989,628,267$ & \\
\hline $\mathrm{NO}_{\mathrm{x}}(\mathrm{kg})$ & $75,513,909$ & & $83,006,485$ & & $67,755,221$ & \\
\hline $\mathrm{SO}_{2}(\mathrm{~kg})$ & $5,246,301$ & & $5,669,269$ & & $4,585,981$ & \\
\hline
\end{tabular}

Table 4: Modal Split and Emissions in Year 2010 for three Transit Time Sensitivities Including Betuweline

\begin{tabular}{|c|c|c|c|c|c|c|}
\hline \multirow[t]{2}{*}{ Time Sensitivity } & \multicolumn{2}{|c|}{$(80 \%)$} & \multicolumn{2}{|c|}{$(60 \%)$} & \multicolumn{2}{|c|}{$(40 \%)$} \\
\hline & Vehicles Used & Modal Split (\%) & Vehicles Used & Modal Split (\%) & Vehicles Used & Modal Split (\%) \\
\hline Trucks (1) & 869,565 & 8.3 & 869,565 & 8.3 & 869,565 & 8.3 \\
\hline Trucks (2) & $3,478,261$ & 33.1 & $1,852,939$ & 17.6 & 434,783 & 4.1 \\
\hline Trucks (3) & $1,739,130$ & 16.6 & $1,739,130$ & 16.6 & $1,273,739$ & 12.1 \\
\hline Betuweline Trains & 50,476 & 17.5 & 50,476 & 17.5 & 50,476 & 17.5 \\
\hline Barges & 7,708 & 20.0 & 15,416 & 40.0 & 22,324 & 57.9 \\
\hline Total & & 95.5 & & 99.9 & & 99.9 \\
\hline \multicolumn{7}{|l|}{ Emissions } \\
\hline $\mathrm{CO}_{2}(\mathrm{~kg})$ & $6,035,507,200$ & & $5,104,974,400$ & & $3,916,180,000$ & \\
\hline $\mathrm{NO}_{\mathrm{x}}(\mathrm{kg})$ & $78,128,576$ & & $65,995,392$ & & $51,839,600$ & \\
\hline $\mathrm{SO}_{2}(\mathrm{~kg})$ & $5,793,968$ & & $4,908,552$ & & $3,851,640$ & \\
\hline
\end{tabular}


Table A-1: Emissions and Energy Consumption 1990, adapted from Van Ierland et al. (2000)

\begin{tabular}{|c|c|c|c|c|}
\hline & $\begin{array}{c}\mathrm{CO}_{2} \\
(\mathrm{~kg} / \text { ton-km) }\end{array}$ & $\begin{array}{c}\mathrm{NO}_{\mathrm{x}} \\
(\mathrm{kg} / \text { ton-km) }\end{array}$ & $\begin{array}{c}\mathrm{SO}_{2} \\
(\mathrm{~kg} / \text { ton-km) }\end{array}$ & $\begin{array}{c}\text { Energy } \\
\text { (Mega-joule/ton-km) }\end{array}$ \\
\hline \multicolumn{5}{|l|}{ Road } \\
\hline Truck (1) & .155 & .00280 & .000167 & 1.82 \\
\hline Truck (2) & .150 & .00210 & .000140 & 1.61 \\
\hline Truck (3) & .145 & .00140 & .000110 & 1.40 \\
\hline Inland Waterways & .039 & .00062 & .000035 & .45 \\
\hline Railway & .032 & .00006 & .000060 & .72 \\
\hline
\end{tabular}

Table A-2: Transportation Costs in Scenarios including Regular Cargo Rail

\begin{tabular}{ccccccc}
\hline Setting: & \multicolumn{2}{c}{ A: $80 \%$ time sensitive } & \multicolumn{2}{c}{ B: $60 \%$ time sensitive } & \multicolumn{2}{c}{ C: $40 \%$ time sensitive } \\
\hline Regime: & $\begin{array}{c}\text { Total Costs } \\
\text { (euro) }\end{array}$ & $\begin{array}{c}\text { (euro/ton- } \\
\mathrm{km})\end{array}$ & $\begin{array}{c}\text { Total Costs } \\
\text { (euro) }\end{array}$ & $\begin{array}{c}\text { (euro/ton- } \\
\mathrm{km})\end{array}$ & $\begin{array}{c}\text { Total Costs } \\
\text { (euro) }\end{array}$ & $\begin{array}{c}\text { (euro/ton- } \\
\mathrm{km})\end{array}$ \\
& $4,970,517,440$ & .1056 & $5,759,654,880$ & .0973 & $5,229,649,600$ & .0865 \\
2 & $5,829,378,613$ & .1238 & $6,628,183,893$ & .1120 & $6,280,346,320$ & .1039 \\
3 & $6,152,905,973$ & .1307 & $7,081,018,613$ & .1197 & $6,945,735,120$ & .1149 \\
\hline
\end{tabular}

Table A-3: Transportation Costs in Scenarios including Dedicated Cargo Rail (Betuweline)

\begin{tabular}{ccccccc}
\hline Setting & & \multicolumn{2}{c}{ A: 60\% time sensitive } & \multicolumn{2}{c}{ C: $40 \%$ time sensitive } \\
\hline Regime & $\begin{array}{c}\text { Total Costs } \\
\text { (euro) }\end{array}$ & $\begin{array}{c}\text { (euro/ton- } \\
\mathrm{km})\end{array}$ & $\begin{array}{c}\text { Total Costs } \\
\text { (euro) }\end{array}$ & $\begin{array}{c}\text { (euro/ton- } \\
\mathrm{km})\end{array}$ & $\begin{array}{c}\text { Total Costs } \\
\text { (euro) }\end{array}$ & $\begin{array}{c}\text { (euro/ton- } \\
\mathrm{km})\end{array}$ \\
1 & $5,658,457,440$ & .0981 & $5,309,300,800$ & .0879 & $4,739,931,600$ & .0784 \\
2 & $6,556,185,280$ & .1137 & $5,989,598,400$ & .0991 & $5,174,278,000$ & .0856 \\
3 & $6,859,572,640$ & .1189 & $6,345,659,200$ & .1050 & $5,571,865,200$ & .0922 \\
\hline
\end{tabular}

\footnotetext{
${ }^{\mathrm{i}}$ Passing a new law in the European Union is a complex process. In essence, the European Commission proposes new legislation, which is in turn adopted by the European Parliament and/or the Council of the European Union. As a rule it takes about three years for any proposed legislation to be adopted by at least eight EU countries.

ii Pollution caused by e.g. the "production, maintenance and ultimate disposal" of vehicles (Van Ierland et al., 2000) must also be considered. The "production of building materials, construction, maintenance and dismantling of the infrastructure" (Van Ierland et al., 2000) indirectly add to the environmental impact of transportation. Yet, these costs are difficult to estimate and they are not to be expected to be charged to
} 
transportation in the near future (up to 2020). Therefore, this study will neglect them and put its focus on the directly to transportation attributable impacts on society.

iii Another form of social costs that could be included is land use. Nature is constantly destroyed when infrastructure is constructed, thereby, taking up space that else would be employed for other purposes. (Campisi and Gastaldi, 1996). A common type of barge will be used as a reference for this study: the vessel of DeCeTe. DeCeTe (Duisburger Container-Terminalgesellschaft) provides transportation of containerized goods between Duisport and the Port of Rotterdam.

${ }^{\text {iv }}$ A recent example of a successful project is the Rhine-Main-Danube-Canal, which was finished in 1992.

${ }^{\mathrm{v}}$ This route is part of a longer corridor: most of the traffic coming from e.g. Switzerland, Italy or Poland passes though the Ruhr Basin. For the purpose of comparing the different modes, all traffic is assumed to commence in the Ruhr Basin and end in Rotterdam.

vi $45.4 *(1+2.9)^{10}=60.424$

vii Diesel tax - including national subsidies - was 0.47 Euros per liter in January 2003 (BGL, 2002).

viii The efficiency of a diesel engine is set to $40 \%$. The efficiency of an electrical traction engine is set to $70 \%$.

ix This figure is based on Van Ierland et al. (2000), who use a figure of 70 billion ton-km for cross-border road traffic related to the Port of Rotterdam. This figure is divided by two since only traffic in one direction is considered in the present study. 